\title{
Characterization of Solid Residues from Entrained Flow Gasification of Coal Bio-Oil Slurry
}

Feng, Ping; Lin, Weigang; Jensen, Peter A.; Song, Wenli; Hao, Lifang; Li, Songgeng; Dam-Johansen, Kim

Published in:

Energy and Fuels

Link to article, DOI:

10.1021/acs.energyfuels.9b04437

Publication date:

2020

Document Version

Publisher's PDF, also known as Version of record

Link back to DTU Orbit

Citation $(A P A)$ :

Feng, P., Lin, W., Jensen, P. A., Song, W., Hao, L., Li, S., \& Dam-Johansen, K. (2020). Characterization of Solid Residues from Entrained Flow Gasification of Coal Bio-Oil Slurry. Energy and Fuels, 34(5), 5900-5906. https://doi.org/10.1021/acs.energyfuels.9b04437

\section{General rights}

Copyright and moral rights for the publications made accessible in the public portal are retained by the authors and/or other copyright owners and it is a condition of accessing publications that users recognise and abide by the legal requirements associated with these rights.

- Users may download and print one copy of any publication from the public portal for the purpose of private study or research.

- You may not further distribute the material or use it for any profit-making activity or commercial gain

- You may freely distribute the URL identifying the publication in the public portal 


\title{
Characterization of Solid Residues from Entrained Flow Gasification of Coal Bio-Oil Slurry
}

\author{
Ping Feng, Weigang Lin,* Peter A. Jensen, Wenli Song,* Lifang Hao, Songgeng Li, \\ and Kim Dam-Johansen
}

Cite This: https://dx.doi.org/10.1021/acs.energyfuels.9b04437

Read Online

\begin{abstract}
ACCESS 1
Ш Metrics \& More

Article Recommendations

ABSTRACT: Char and soot characterization was performed on samples obtained from pilot-scale entrained flow gasification of coal bio-oil slurry (CBS) and coal/water slurry (CWS) at different operating conditions. The compositions and gasification reactivity of char and soot have been investigated to reveal the difference of CBS and CWS slurries. The results show that both char and soot obtained from CBS gasification contain alkali and alkaline earth metals which come from the bio-oil. These CBS char and soot alkalicontaining samples exhibit higher gasification reactivity than those from CWS gasification. For CBS gasification, soot has higher gasification reactivity compared with char. The gasification reactivity may be caused by the catalytic effect of $\mathrm{KCl}_{\text {and }} \mathrm{K}_{2} \mathrm{SO}_{4}$ existing in char and soot. The reactivity of char and soot is also influenced by the gasification conditions (such as $\mathrm{H}_{2} \mathrm{O} / \mathrm{C}$ ratio), and high $\mathrm{CO}_{2}$ gasification reactivity is observed for chars exposed to high $\mathrm{H}_{2} \mathrm{O} / \mathrm{C}$ ratios in the entrained flow reactor.
\end{abstract}

\section{INTRODUCTION}

Biomass is a carbon containing a renewable energy resource ${ }^{1-4}$ and can be used to produce syngas, chemicals, heat, and power. However, direct utilization of biomass in large-scale units is, to some degree, limited because of its low energy density and high transportation cost. By fast pyrolysis to bio-oil, the energy density of biomass can be increased. ${ }^{5}$ Bio-oil is of high water content and oxygen content, ${ }^{6-8}$ and this makes it difficult for direct utilization. Institute of Process Engineering, Chinese Academy of Sciences, has proposed a path for bio-oil utilization, which is blending bio-oil with coal powders for the preparation of coal bio-oil slurry (CBS). ${ }^{9}$ The slurry provides a heating value from both bio-oil and coal, and it can be considered as a partial green fuel. ${ }^{10,11}$

In our previous study, the rheology ${ }^{10}$ and gasification performance $^{12}$ of CBS have been investigated. The studies have shown the feasibility of production of syngas from a CBS. Entrained flow gasification reactors usually operate between 1200 and $1600{ }^{\circ} \mathrm{C}$ and with short residence time. The gasification of slurry can be described by the process steps of evaporation of water, release of volatiles, and gasification of char. The second step includes heterogeneous gas-solid reactions, which is the controlling step in the whole process. For this reason, previously in getting a detailed understanding of CBS gasification, the investigation on char and soot characterization was of essential importance. The reactivity of char and soot, as the main feature which determines the progress in the gasification stage, largely depends on its composition and parenting fuels. The most significant difference between CBS and coal/water slurry (CWS) is that the content of AAEMs from bio-oil may remain in char or soot, which may influence the gasification performance. The aim of the study was to analyze the synergy of bio-oil and coal in char or soot gasification, which is the controlling step in gasification. The experimental results may provide recommendations in choosing operating conditions such as temperature, residence time and $\mathrm{H}_{2} \mathrm{O} / \mathrm{C}$, and design of reactors.

Characterization of solid residues (char and soot) from biomass gasification/pyrolysis has been widely investigated. Various factors can influence the characteristics of char and soot, including but not limited to temperature, residence time, oxygen equivalence ratio, pressure, and fuel properties. Soot is formed by the secondary reactions of volatiles from biomass thermal-cracking requiring a certain high temperature $(>1000$ ${ }^{\circ} \mathrm{C}$ ) and long volatile residence time $(2 \mathrm{~s}) .{ }^{13}$ The particle shape and nanostructure of soot at high temperatures $\left(>1430{ }^{\circ} \mathrm{C}\right)$ were a function of the inorganic content and of the inorganic elements the individual particle consisted of. ${ }^{14}$ Char and soot yields significantly decrease as the equivalence ratio increases. ${ }^{15}$ In oxygen-blown biomass gasification, the submicron fly ash particles contain high proportions of refractory elements ( $\mathrm{Ca}, \mathrm{Mg}$, and $\mathrm{Si}$ ) and the more volatile elements $(\mathrm{K}, \mathrm{Na}, \mathrm{S}$, and Cl). ${ }^{16}$ Septien ${ }^{17}$ and Misra ${ }^{18}$ have found that char and soot from biomass fast pyrolysis contains carbonaceous structure, crystallization of inorganics, and remains of potassium. The reactivity of soot generated at high temperatures $\left(1400{ }^{\circ} \mathrm{C}\right)$ was higher than that at lower temperatures. ${ }^{19}$ Qin et al. ${ }^{20}$ investigated char and soot from biomass gasification and concluded that char is more reactive than soot. However,

Received: December 22, 2019

Revised: March 10, 2020

Published: March 16, 2020 
Table 1. Proximate Analysis and Ultimate Analysis of Coal Sample

\begin{tabular}{|c|c|c|c|c|c|c|c|c|c|}
\hline \multirow[b]{2}{*}{ sample } & \multicolumn{4}{|c|}{ proximate analysis (wt \%) } & \multicolumn{5}{|c|}{ ultimate analysis (wt \%) } \\
\hline & $M_{\mathrm{ad}}$ & $V_{\text {ad }}$ & $A_{\mathrm{ad}}$ & $\mathrm{FC}_{\mathrm{ad}}$ & $\mathrm{C}_{\mathrm{d}}$ & $\mathrm{H}_{\mathrm{d}}$ & $\mathrm{O}_{\mathrm{d}}$ & $\mathrm{N}_{\mathrm{d}}$ & $S_{d}$ \\
\hline Columbia coal & 6.60 & 33.90 & 8.80 & 50.70 & 73.13 & 4.93 & 10.34 & 1.50 & 0.68 \\
\hline
\end{tabular}

Table 2. Composition of Ash (Oxides) in Coal

$\begin{array}{lcccccccccc}\text { species } & \mathrm{Al}_{2} \mathrm{O}_{3} & \mathrm{CaO} & \mathrm{Fe}_{2} \mathrm{O}_{3} & \mathrm{~K}_{2} \mathrm{O} & \mathrm{MgO} & \mathrm{Na}_{2} \mathrm{O} & \mathrm{P}_{2} \mathrm{O}_{5} & \mathrm{SO}_{3} & \mathrm{SiO}_{2} & \mathrm{TiO}_{2} \\ \text { result (\%) } & 19 \pm 2 & 2.1 \pm 0.2 & 8.2 \pm 0.7 & 2.0 \pm 0.2 & 2.1 \pm 0.1 & 1.0 \pm 0.1 & 0.18 \pm 0.06 & 2.4 \pm 0.3 & 56 \pm 5 & 0.85 \pm 0.07\end{array}$

Table 3. Elemental Analysis of Ash-Forming Elements in the Bio-Oil (Dry Basis)

$\begin{array}{llllllllll}\text { element } & \mathrm{S} & \mathrm{Cl} & \mathrm{Al} & \mathrm{Ca} & \mathrm{Fe} & \mathrm{K} & \mathrm{Mg} & \mathrm{Na} & \mathrm{P} \\ \text { result }(\mathrm{mg} / \mathrm{kg}) & 40 & 71 & 32 & 2700 & 390 & 9400 & 820 & 46 & 430\end{array}$

characterization of char and soot from slurry gasification is scarce. Compared with char and soot from biomass gasification, solids produced from slurry gasification may not maintain the features of biomass. Instead, their characteristics may be closely related with both the liquid and solid phase in the slurry. Our previous research shows that CBS is superior in carbon conversion and syngas yields compared with CWS. The difference in the liquid medium of the slurry may change the properties of solid residues and consequently affect their gasification performance. In this work, the char and soot generated from CBS gasification were studied. The morphology, composition, and gasification reactivity of char and soot produced by CBS were investigated in comparison with those from CWS. The ash composition (especially alkali and alkaline earth metals) in bio-oil is provided for verification of their promotion in CBS gasification.

\section{EXPERIMENTAL SECTION}

2.1. Materials. Solid residues analyzed in the present study were produced from CBS gasification or CWS gasification in a hightemperature entrained flow reactor. A detailed description of the reactor system can be found in the paper on gasification of coal bio-oil slurries. ${ }^{12}$ The bio-oil is a straw pyrolysis liquid from a pilot plant at Karlsruhe Institute of Technology (KIT). Columbia bituminous coal is used with an average particle size of $18.7 \mu \mathrm{m}$. The coal fraction in CBS varies from 10 to $30 \%$ by weight. The gasification of slurries was carried out at $1300{ }^{\circ} \mathrm{C}$. The sampling system for solid was described in our previous study, and during sampling, the system was kept at $400{ }^{\circ} \mathrm{C}$ for preventing tar and moisture from condensation. The solid residues include char and soot. Char was collected in a cyclone, in which the cutting size of solids is about $3-5 \mu \mathrm{m}$. Soot was collected in a metal filter after the cyclone. The cyclone and filter were both heated up to $300{ }^{\circ} \mathrm{C}$ during sampling to prevent tar from condensation.

Ultimate analysis $(\mathrm{C}, \mathrm{H}, \mathrm{N}$, and $\mathrm{S})$ of coal, char, and soot was carried out on an elemental analyzer (Elementar Vario). The proximate analysis and ultimate analysis of the coal sample are shown in Table 1. The ash composition of coal was determined by inductively coupled plasma-optical emission spectrometry (ICPOES) radial after pressurized digestion by FORCE Technology, Denmark. The sulfur and chlorine content in bio-oil was determined based on DS/EN 15289 (2011). The carbon content, hydrogen content, and nitrogen content were determined based on DS/EN 15104 (2011). The content of other elements (such as $\mathrm{Al}, \mathrm{Ca}, \mathrm{Fe}, \mathrm{K}$ $\mathrm{Mg}, \mathrm{Na}, \mathrm{P}, \mathrm{Si}$, and $\mathrm{Ti}$ ) was determined by ICP-OES based on DS/ EN 15290 (2011), which were all supported by FORCE Technology, Denmark. The composition of ash (oxides) in coal and inorganic elements of the bio-oil is shown in Tables 2 and 3, respectively. The coal ash was dominated by the elements $\mathrm{Si}, \mathrm{Al}$, and $\mathrm{Fe}$, while the highest concentration of ash-forming elements in the bio-oil was $\mathrm{K}$ and $\mathrm{Ca}$.
2.2. Thermogravimetric Analysis. The peak temperature $\left(T_{p}\right)$ in the differential thermogravimetry (DTG) curve was used to represent the gasification reactivity of char and soot with respect to $\mathrm{CO}_{2}$, and it was determined by a nonisothermal program using a thermogravimetric analyzer (Netzsch STA-449, Germany). An example of the DTG curve was shown in Figure 1. In each test, a

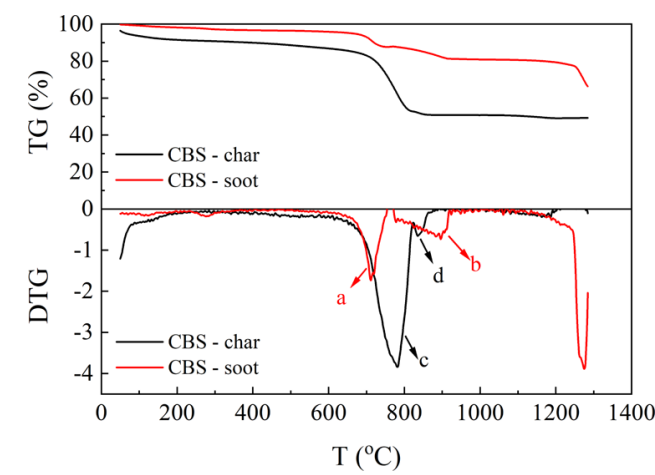

Figure 1. TGA curves of char and soot from CBS gasification.

sample of about $5 \mathrm{mg}$ was weighted and loaded into an open alumina crucible. Before the run, the atmosphere was switched to $\mathrm{CO}_{2}$. Then, the samples were heated from an ambient temperature to $1300{ }^{\circ} \mathrm{C}$ with a fixed heating rate of $10{ }^{\circ} \mathrm{C} / \mathrm{min}$. The system was cooled down in $\mathrm{CO}_{2}$ atmosphere when the gasification was finished. The flow rate of $\mathrm{CO}_{2}$ was kept constant at $50 \mathrm{~mL} / \mathrm{min}$.

2.3. XRD and SEM Analysis. Char and soot were analyzed by a diffractometer (SmartLab (9), Japan) to identify the phases in inorganic materials. Scans were conducted at the scanning range from 5 to $90^{\circ}$ of $2 \theta$ with a scanning rate of $2^{\circ} / \mathrm{min}$ and the step size of $0.033^{\circ}$. The morphology and elemental composition on the surface of char and soot were performed on a scanning electron microscopy equipped with an energy-dispersive X-ray technique (SEM-EDS, JSM-7001F+INCA X-MAX, Japan).

\section{RESULTS AND DISCUSSION}

3.1. Influence of Fuel Types on Solid Reactivity. The TG and DTG curves of gasification of char and soot generated by CBS and CWS are shown in Figures 1 and 2, respectively. The char and soot were produced in the entrained flow reactor by gasification of CBS and CWS at $1300{ }^{\circ} \mathrm{C}$ at a molar ratio $\mathrm{H}_{2} \mathrm{O} / \mathrm{C}$ of 5.0 with a residence time about $1.0 \mathrm{~s}$. As temperature increased from room temperature to $1300{ }^{\circ} \mathrm{C}$ under $\mathrm{CO}_{2}$ gasification, it is seen that for both char and soot from CBS two weight loss peaks in the DTG curves are observed, corresponding to peak a and peak $b$ of char and peak $\mathrm{c}$ and peak $\mathrm{d}$ of soot, as shown in Figure 1. However, there was only one weight loss peak for CWS (shown in Figure 2). 


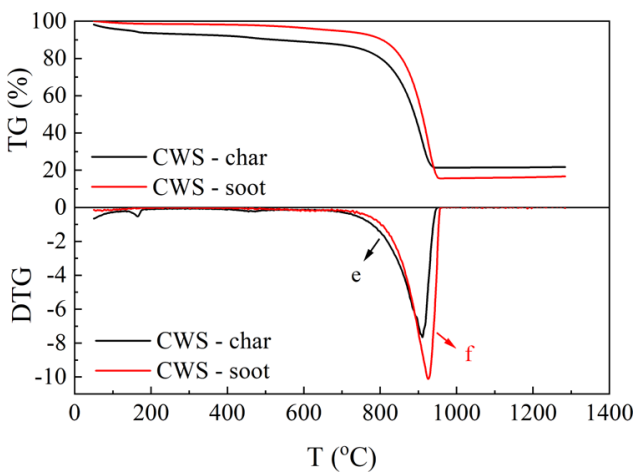

Figure 2. TGA curves of char and soot from CWS gasification.

To determine the gasification temperature of the solid residue, the weight loss of peaks in Figures 1 and 2 is compared with the carbon content in the solids, as shown in Table 4 . It is

Table 4. Carbon Content in Char and Soot from Various Fuels

\begin{tabular}{llllll} 
& \multicolumn{2}{c}{ CBS } & & \multicolumn{2}{c}{ CWS } \\
\cline { 2 - 3 } \cline { 5 - 6 } & \multicolumn{1}{c}{ char } & soot & & char & soot \\
carbon content & 35.83 & 7.00 & & 66.93 & 79.71 \\
weight loss in TG & $36.80($ a) & $7.13(\mathrm{c})$ & & $70.77(\mathrm{e})$ & $82.47(\mathrm{f})$
\end{tabular}

very clear that weight loss in DTG curves for peaks a, c, e and f is in accordance with the carbon content in the char and soot, as the main reaction happened is carbon gasification in $\mathrm{CO}_{2}$. Thus, the maximum gasification rate temperature $\left(T_{\mathrm{p}}\right)$ for char and soot could be obtained, and it is shown in Table 5 . The $T_{p}$

Table 5. Gasification Temperature $\left(T_{\mathrm{p}}\right)$ of Char and Soot with $\mathrm{CO}_{2}$

\begin{tabular}{lcc} 
& char & soot \\
CBS & $780^{\circ} \mathrm{C} \mathrm{(c)}$ & $710^{\circ} \mathrm{C} \mathrm{(a)}$ \\
CWS & $911{ }^{\circ} \mathrm{C} \mathrm{(e)}$ & $925^{\circ} \mathrm{C}(\mathrm{f})$ \\
\hline
\end{tabular}

of solid residues from CWS was $910-925^{\circ} \mathrm{C}$. While for CBS, it is about 710 and $780{ }^{\circ} \mathrm{C}$, respectively. It shows that char and soot of CBS have higher gasification reactivity than those of CWS, and soot of CBS has higher gasification reactivity than char.

To investigate the difference in gasification reactivity, char and soot were further characterized by SEM-EDS for morphology and elemental distribution on the surface. The SEM images and EDS spectra of char and soot are shown in Figures 3-5. It was found from Figure 3 that char of CWS and CBS are mostly particulates of several micrometers with irregularly shapes. The particle sizes are within the same order of magnitude as the coal particles used for preparing the slurries, which is in accordance with the conclusion that the char mainly arises from the coal in the slurries. As seen in Figure 3, soot is composed of even smaller particles with diameters about $20 \mathrm{~nm}$, and these particles agglomerate on the filter surface. Especially for soot of CWS, the soot agglomerate particles demonstrated fairly good sphericity, whose morphologies were remarkably similar to soot or fly ash formed from coal by pyrolysis or combustion, as reported in the literature. $^{21-29}$ They are also called ultrafine particulate matters $\left(\mathrm{PM}_{10}\right.$ or even $\left.\mathrm{PM}_{0.22-10}\right)$. Most of them are AAEM related or
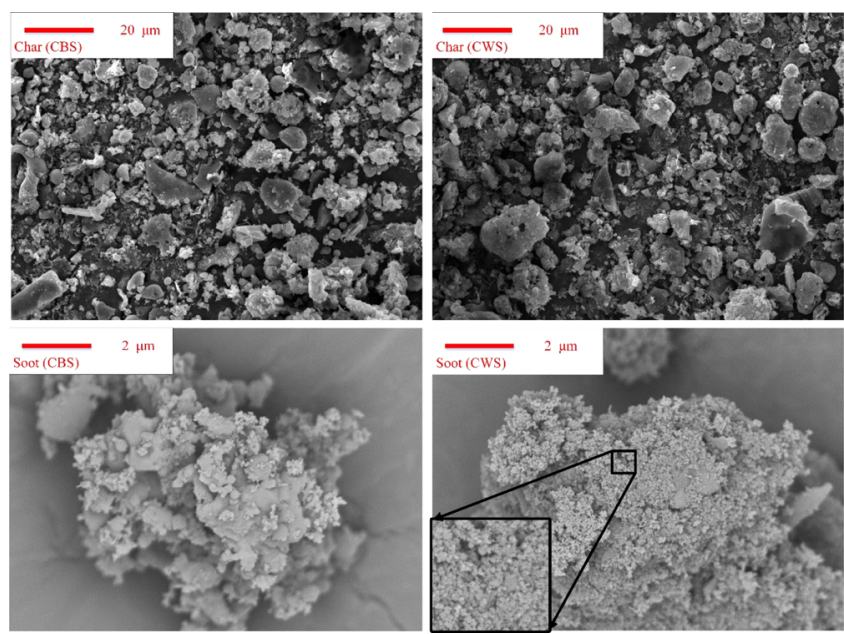

Figure 3. SEM images of char and soot obtained from CBS and CWS.
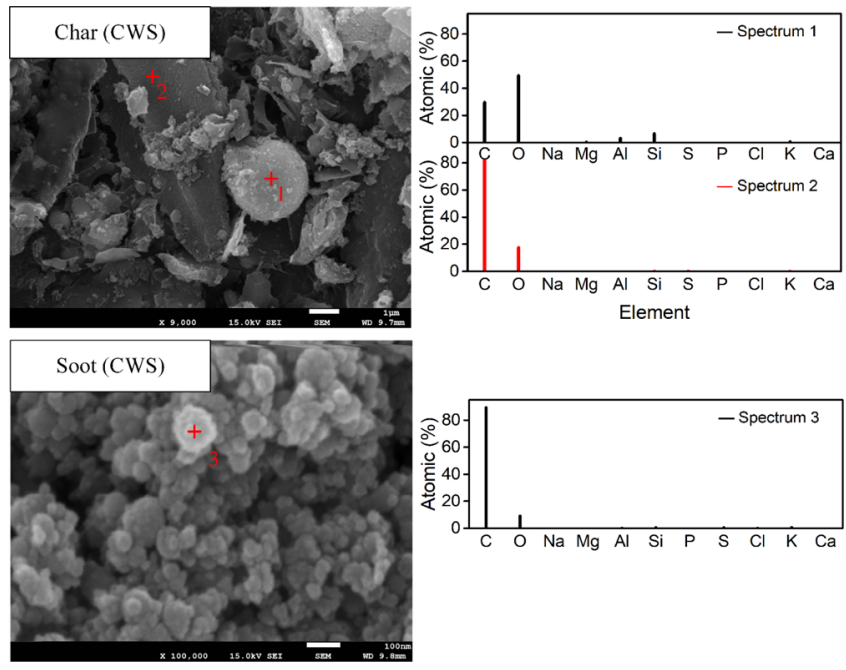

Figure 4. EDS spectra of char and soot obtained from gasification of CWS.

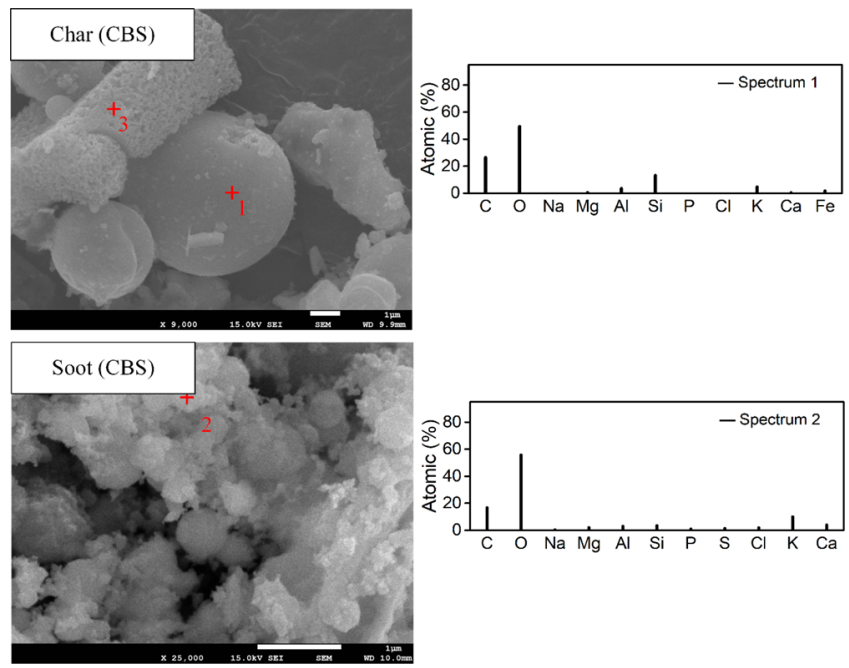

Figure 5. EDS spectra of char and soot obtained from gasification of CBS.

contains $\mathrm{Al}$ or $\mathrm{Si}$ because the organic macromolecular structure of fuel was consumed by the reaction with the gasifying agent, 
leading to the exposure of the inorganic species and intensive emission of PM.

Figure 4 shows the EDS spectra of char and soot from CWS gasification. Char contains carbon particulates (spot 2 in Figure 4) and spherical aluminosilicates (spot 1 in Figure 4). These aluminosilicates mainly come from ash in coal. They are spherical because they melt during gasification as the reactor temperature is higher than their melting point temperature (around $1200{ }^{\circ} \mathrm{C}$ ). Soot of CWS is mainly composed of carbon, as shown in the EDS spectra spectrum 3 in Figure 4. The carbon in CWS contributes both to char and soot formation in entrained flow gasification, while the ash of the CWS forms the aluminosilicate sphere with several micrometers.

The EDS spectra of char and soot from CBS gasification are shown in Figure 5. Similar to the CWS char, carbon particles and aluminosilicates balls were found in the char from CBS. However, the carbon particles generated by CBS were porous (spot 3), and the observed aluminosilicate balls include not only aluminum and silica, but also potassium. Even higher contents of potassium were found in CBS soot. As mentioned in the Experimental Section, bio-oil contains a relatively high content of potassium. This is the main source for potassium deposition in char and soot. It is important to note the existence of the potassium compounds because they were reported to have a catalytic effect on gasification. In comparison with char produced from CWS, both types of char particles (irregular shape particles and the spherical shape particles) were identified, which is similar to the char obtained from biomass gasification. ${ }^{30}$ However, the char produced by CBS has more similarities on morphology, which includes smoother surface of the spherical particles, and more porosity developed irregular particles. The former is due to production from the fragmentation of char particles, while the latter is because of variations in silicon content ${ }^{31}$ and was closely associated with the eutectic minerals with low melting temperatures in char particles, which mainly contain $\mathrm{Ca} / \mathrm{K}$ / $\mathrm{Si} / \mathrm{Al}$. Soot of CBS and biomass both tend to agglomerate and coagulate to form soot clusters. ${ }^{16,29,32}$ On chemical composition, after gasification, the AAEMs exist in char and soot for both biomass and CBS. Especially in soot, the key elements present are $\mathrm{Na}, \mathrm{K}$, and $\mathrm{Cl}$ because of the condensation of these inorganic species during the cooling of flue gas or as the result from the reactions between soot and alkali metals. ${ }^{29}$ Most of compounds of AAEMs in char and soot are water soluble. ${ }^{13}$ The difference for the two fuels lies in which are richer in AAEMs on char and soot and the activity of char and soot. In the literature, char obtained from biomass are more reactive than soot. ${ }^{17,20}$ However, for CBS, there is rich content of potassium in bio-oil other than coal, and they are released into the volatile phase in the form of vapors, flow into the lower temperature region, condense, grow, partly adsorbed by soot particles, and consequently ascribed higher AAEM contents in soot than char and higher reactivity of soot than char. In any case, potassium content played a more important role on the soot or char reactivity than the particle size. ${ }^{19}$

The potassium compounds were further detected by X-ray diffraction (XRD), as shown in Figure 6. $\mathrm{KCl}$ and $\mathrm{K}_{2} \mathrm{SO}_{4}$ were both found in char and soot from CBS. The contents of $\mathrm{KCl}$ and $\mathrm{K}_{2} \mathrm{SO}_{4}$ are higher in soot. $\mathrm{SiO}_{2}$ was found only in char, which confirms that char is mostly derived from the coal particles. In comparison with char and soot from CBS, only $\mathrm{SiO}_{2}$ was found in both char and soot from CWS (shown in

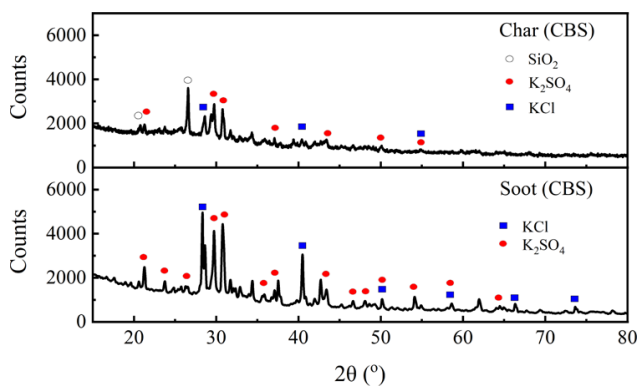

Figure 6. XRD spectra of char and soot obtained from gasification of CBS.

Figure 7). The content of $\mathrm{SiO}_{2}$ in soot of CWS was relatively low.

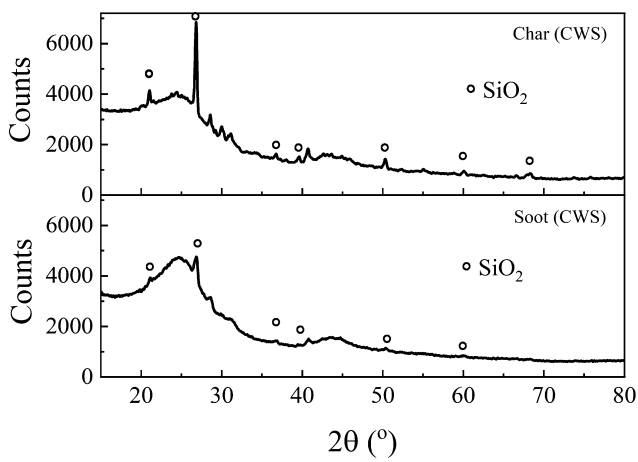

Figure 7. XRD spectra of char and soot obtained from gasification of CWS.

The existence of $\mathrm{KCl}$ may explain the secondary weight loss peak $b$ and peak d in DTG curves in Figure 1. Arvelakis et al. ${ }^{33}$ determined the temperature of volatilization of K-containing species by thermogravimetric analysis (TGA). At a temperature range within $850-1150{ }^{\circ} \mathrm{C}$, the mixture of $\mathrm{KCl}+\mathrm{K}_{2} \mathrm{SO}_{4}$ and $\mathrm{KCl}+\mathrm{SiO}_{2}$ shows weight loss because of evaporation of $\mathrm{KCl}$. According to Vassilev et al., ${ }^{34}$ the decomposition of $\mathrm{K}_{2} \mathrm{SO}_{4}$ occurs between 900 and $1100{ }^{\circ} \mathrm{C}$, and the decomposition could be finished at $900{ }^{\circ} \mathrm{C}$ due to the reduction by carbon. In the present study, the secondary weight loss peaks $b$ and $d$ fall in the temperature range of 850 to $1150{ }^{\circ} \mathrm{C}$, in which the evaporation of $\mathrm{KCl}$ and decomposition of $\mathrm{K}_{2} \mathrm{SO}_{4}$ will take place. This makes it sensible that peaks $b$ and $d$ are attributed to alkali metal volatilization.

It has been shown by many researchers that $\mathrm{KCl}$ and $\mathrm{K}_{2} \mathrm{SO}_{4}$ have a catalytic effect during gasification. ${ }^{35-37}$ In order to verify if the difference in gasification reactivity between solids from CWS and CBS was caused by $\mathrm{KCl}$ and $\mathrm{K}_{2} \mathrm{SO}_{4}$, further studies were performed. The char and soot of CBS was treated with $\mathrm{HCl}$ to remove $\mathrm{KCl}$ and $\mathrm{K}_{2} \mathrm{SO}_{4}$. These solids were prepared by dipping the solid particles in an aqueous solution of $\mathrm{HCl}(2 \mathrm{~mol} / \mathrm{L})$ for $8 \mathrm{~h}$ and then rinsed with deionized water until the $\mathrm{pH}$ of the rinsing water became neutral. The acid washed char was dried at $105{ }^{\circ} \mathrm{C}$ for $24 \mathrm{~h}$. Then, they were gasified in the thermogravimetric analyzer with $\mathrm{CO}_{2}$ under the same conditions as the other samples, and the results are shown in Figure 8. The acid-treated solids present a single weight loss peak and the $T_{\mathrm{p}}$ is around $1000^{\circ} \mathrm{C}$, which is higher than the $T_{\mathrm{p}}\left(710-780^{\circ} \mathrm{C}\right)$ of untreated solids. This shows that the weight loss for secondary peaks in Figure 1 is indeed caused by $\mathrm{KCl}$ and $\mathrm{K}_{2} \mathrm{SO}_{4}$; moreover, these compounds in the 


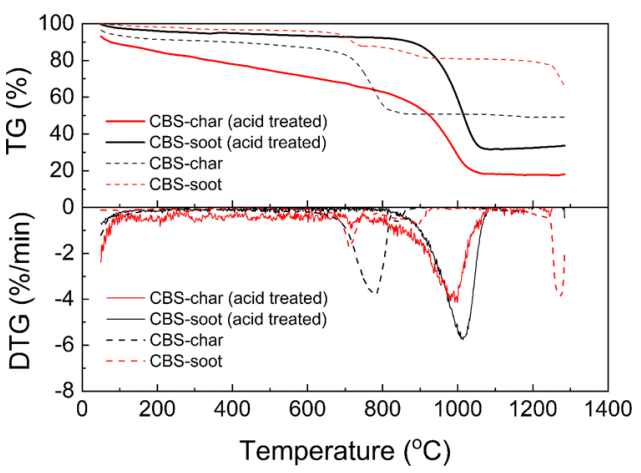

Figure 8. TGA gasification of acid-treated char and soot from CBS.

char and soot favors reduction of the gasification temperature. It also suggests that the difference in gasification reactivity of solid residues from CBS and CWS may attribute to the potassium in the bio-oil.

3.2. Influence of the Steam/Carbon Molar Ratio in Gasification on Solid Gasification Reactivity. The steam/ carbon molar ratio $\left(\mathrm{H}_{2} \mathrm{O} / \mathrm{C}\right)$ is a significant factor in gasification because it greatly influences the syngas composition and carbon conversion. ${ }^{12,38}$ The char and soot composition depends on $\mathrm{H}_{2} \mathrm{O} / \mathrm{C}$ as well. The gasification TGA curves of solids obtained under different $\mathrm{H}_{2} \mathrm{O} / \mathrm{C}$ ratios are shown in Figures 9 and 10. The starting value of $\mathrm{H}_{2} \mathrm{O} / \mathrm{C}$ is

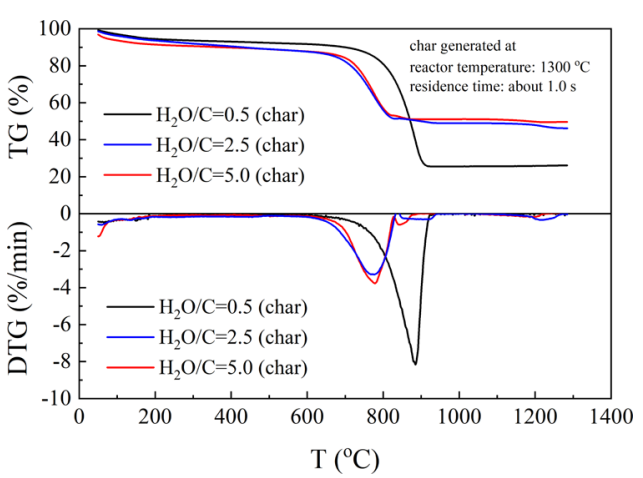

Figure 9. TGA curves of char from CBS under different $\mathrm{H}_{2} \mathrm{O} / \mathrm{C}$.

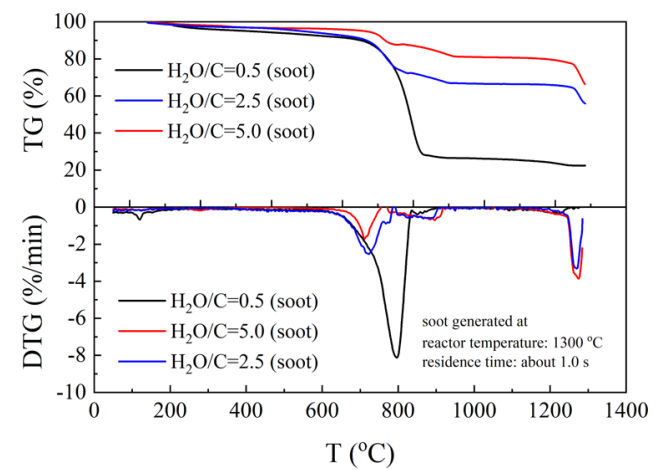

Figure 10. TGA curves of soot from CBS under different $\mathrm{H}_{2} \mathrm{O} / \mathrm{C}$.

0.5 due to high water content in bio-oil. With increasing steam addition, $\mathrm{H}_{2} \mathrm{O} / \mathrm{C}$ increased from 0.5 to 5 , and simultaneously the steam concentration in the EFR reactor increased from 1.8 to $17 \%$. Char produced under $\mathrm{H}_{2} \mathrm{O} / \mathrm{C}$ of 2.5 and 5 has similar maximum gasification rate temperature $\left(780{ }^{\circ} \mathrm{C}\right)$, and this is lower than the gasification temperature $\left(840{ }^{\circ} \mathrm{C}\right)$ of char obtained at $\mathrm{H}_{2} \mathrm{O} / \mathrm{C}$ of 0.5 . Soot obtained at $\mathrm{H}_{2} \mathrm{O} / \mathrm{C}$ of 2.5 and 5 also presents lower gasification temperature than soot obtained at $\mathrm{H}_{2} \mathrm{O} / \mathrm{C}$ of 0.5 . This shows that the reactivity of solid residues was also affected by gasification conditions.

At the condition of high $\mathrm{H}_{2} \mathrm{O} / \mathrm{C}$, only a small amount of soot and char is captured in the collection system, as shown in Figure 11, which means the high concentration of $\mathrm{H}_{2} \mathrm{O}$ favors

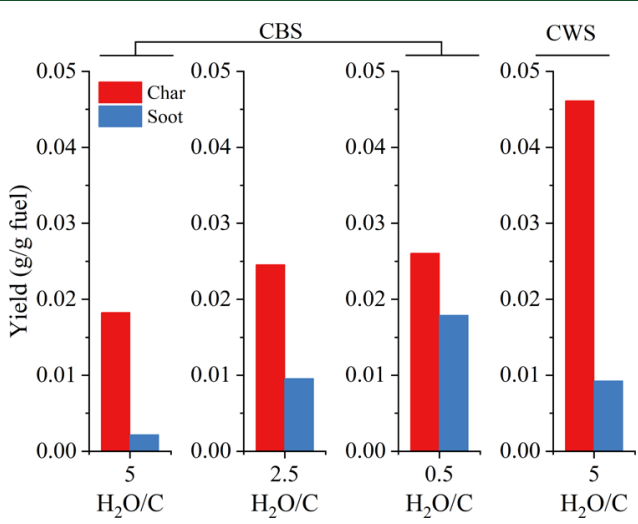

Figure 11. Char and soot yields of CWS and CBS under different $\mathrm{H}_{2} \mathrm{O} / \mathrm{C}$.

the conversion of carbon at $1300{ }^{\circ} \mathrm{C}$. This is in constant with the gasification results that carbon conversion is the highest at this condition. When $\mathrm{H}_{2} \mathrm{O} / \mathrm{C}$ decreased to 0.5 , the yield of char and soot increased significantly. More char and soot containing higher content of carbon were residual and result in larger weight loss, as shown in Figures 9 and 10 . High $\mathrm{H}_{2} \mathrm{O}$ to carbon ratios result in an increase of the reaction possibility of gas agents with char and soot. Moreover, the gaseous species such as $\mathrm{H}_{2} \mathrm{O}$ is important to the formation of ash spheres ${ }^{39}$ and the evolution of char properties. ${ }^{40}$ More pores and surface areas are obtained at a $\mathrm{H}_{2} \mathrm{O}$ atmosphere, and the $\mathrm{H}_{2} \mathrm{O}$ preferred to react with aromatic carbon, which causes char and soot produced at high $\mathrm{H}_{2} \mathrm{O} / \mathrm{C}$ has higher activity. Compared with $\mathrm{CBS}$, the char and soot yield of CWS at high $\mathrm{H}_{2} \mathrm{O} / \mathrm{C}$ (such as 5) was twice more, which implies that CBS promotes carbon conversion at the same conditions. Similar to cogasification of biomass and coals, CBS gasification presents synergy behavior because bio-oil has the same AAEM species as their parent biomass. The evaporation of AAEMs during gasification and their condensation on solid residues may improve the reactivity and reduce the residue yields at the same time. ${ }^{41-43}$

Though the proposal of CBS is to replace CWS without making much modifications to the existing commercial boiler or reactor, some minor changes can be improved in system design based on the experimental results. According to the characteristics of the fuel, such as low char and soot production at $1300{ }^{\circ} \mathrm{C}$ and the shorter resident time reaching high carbon conversion rate, the gasifier for CBS may not require a large height, which is conducive in saving space. The AAEMs in biooil on the one hand is helpful on gasification. On the other hand, they are likely to lead a reduction in ash fusion temperature which may cause problems in discharging for some reactors. Because of the thermal sensitivity of bio-oil, the nozzle needs to be cooled under $60{ }^{\circ} \mathrm{C}$ before slurry atomization into the reactor. These changes may not affect the whole gasification system significantly. Thus, the experiments provide a promising application prospect in the future. 


\section{CONCLUSIONS}

The char and soot obtained from entrained flow gasification of CWS and CBS have been characterized, and the main conclusions drawn from the present study are as follows:

- The composition of the solid residue of CBS and CWS was different. Potassium from the bio-oil was found in char and soot after CBS gasification, while it was not found in solids from CBS gasification.

- The potassium salts in char and soot from CBS mainly consists of $\mathrm{KCl}$ and $\mathrm{K}_{2} \mathrm{SO}_{4}$. Their catalytic effect on gasification was probably the main reason for the higher gasification reactivity of char and soot obtained from CBS compared to CWS.

- Char and soot from CBS exhibit higher gasification reactivity than those from CWS. Soot generated from CBS has higher gasification reactivity than char. The gasification reactivity of char and soot from CBS also depends on the gasification conditions such as the applied $\mathrm{H}_{2} \mathrm{O} / \mathrm{C}$ ratio used during EFR gasification.

\section{AUTHOR INFORMATION}

\section{Corresponding Authors}

Weigang Lin - Department of Chemical and Biochemical Engineering, Technical University of Denmark, $2800 \mathrm{Kgs}$. Lyngby, Denmark; Sino-Danish College, University of Chinese Academy of Sciences, 100190 Beijing, P. R. China;

Phone: (45) 45252835; Email: wl@kt.dtu.dk

Wenli Song - State Key Laboratory of Multiphase Complex Systems, Institute of Process Engineering, Chinese Academy of Sciences, 100190 Beijing, P. R. China; Sino-Danish College, University of Chinese Academy of Sciences, 100190 Beijing, P. R. China; Phone: (8610) 82544963; Email: wlsong@ ipe.ac.cn

\section{Authors}

Ping Feng - China University of Mining and Technology (Beijing), Beijing 100083, P. R. China; State Key Laboratory of Multiphase Complex Systems, Institute of Process Engineering, Chinese Academy of Sciences, 100190 Beijing, P. R. China; Department of Chemical and Biochemical Engineering, Technical University of Denmark, 2800 Kgs. Lyngby, Denmark; Sino-Danish College, University of Chinese Academy of Sciences, 100190 Beijing, P. R. China; 이이이.org/0000-0002-7097$915 \mathrm{X}$

Peter A. Jensen - Department of Chemical and Biochemical Engineering, Technical University of Denmark, $2800 \mathrm{Kgs}$. Lyngby, Denmark; 이이.org/0000-0001-6784-5321

Lifang Hao - State Key Laboratory of Multiphase Complex Systems, Institute of Process Engineering, Chinese Academy of Sciences, 100190 Beijing, P. R. China

Songgeng Li - State Key Laboratory of Multiphase Complex Systems, Institute of Process Engineering, Chinese Academy of Sciences, 100190 Beijing, P. R. China; Department of Chemical and Biochemical Engineering, Technical University of Denmark, 2800 Kgs. Lyngby, Denmark

Kim Dam-Johansen - Department of Chemical and Biochemical Engineering, Technical University of Denmark, 2800 Kgs. Lyngby, Denmark

Complete contact information is available at: https://pubs.acs.org/10.1021/acs.energyfuels.9b04437

\section{Notes}

The authors declare no competing financial interest.

\section{ACKNOWLEDGMENTS}

This study is supported by the National Key R\&D Program of China (2018YFB0605405), International S\&T Cooperation Program of China (2013DFG62640) funded by MOST, SinoDanish collaboration project (DANCNGAS) funded by Innovation Fund Denmark, Technical University of Denmark, China Scholarship Council, The National Natural Science Foundation of China (51104137), and the Open Research Fund of State Key Laboratory of Multiphase Complex Systems (MPCS-2017-D-12).

\section{REFERENCES}

(1) Demirbas, A. Biofuels securing the planet's future energy needs. Energy Convers. Manage. 2009, 50, 2239-2249.

(2) Sarkar, S.; Kumar, A.; Sultana, A. Biofuels and biochemicals production from forest biomass in Western Canada. Energy 2011, 36, 6251-6262.

(3) Shuit, S. H.; Tan, K. T.; Lee, K. T.; Kamaruddin, A. H. Oil palm biomass as a sustainable energy source: A Malaysian case study. Energy 2009, 34, 1225-1235.

(4) Putun, A.; Apaydın, E.; Pütün, E. Rice straw as a bio-oil source via pyrolysis and steam pyrolysis. Energy 2004, 29, 2171-2180.

(5) Mohan, D.; Pittman, C. U.; Steele, P. H. Pyrolysis of Wood/ Biomass for Bio-oil: A Critical Review. Energy Fuels 2006, 20, 848889.

(6) Oasmaa, A.; Peacocke, C. A Guide to Physical Property Characterisation of Biomass-Derived Fast Pyrolysis Liquids; 9513858782; Technical Research Centre of Finland, VTT, 2001.

(7) Oasmaa, A.; Peacocke, C. Properties and Fuel Use of BiomassDerived Fast Pyrolysis Liquids; Technical Research Centre of Finland, VTT \& Conversion and Resource Evaluation Ltd., 2010; p 79.

(8) Oasmaa, A.; Leppämäki, E.; Koponen, P.; Levander, J.; Tapola, E. Physical Characterisation of Biomass-Based Pyrolysis Liquids; Technical Research Centre of Finland: Finland, 1997.

(9) Wang, Y.; Wang, Z.; Li, S.; Lin, W.; Song, W. Experimental study of rheological behavior and steam gasification of coal bio-oil slurry. Energy Fuels 2010, 24, 5210-5214.

(10) Feng, P.; Hao, L.; Huo, C.; Wang, Z.; Lin, W.; Song, W. Rheological behavior of coal bio-oil slurries. Energy 2014, 66, 744749.

(11) Feng, P.; Lin, W.; Clausen, S.; Jensen, P. A.; Huo, C.; Song, W.; Dam-Johansen, K., Performance of pilot-scale atomizers for feeding of coal/bio-oil slurry to an entrained flow gasifier. In 23rd European Biomass Conference and Exhibition: Vienna, Austria, 2015.

(12) Feng, P.; Lin, W.; Jensen, P. A.; Song, W.; Hao, L.; Raffelt, K.; Dam-Johansen, K. Entrained flow gasification of coal/bio-oil slurries. Energy 2016, 111, 793-802.

(13) Wang, X.; Bai, S.; Jin, Q.; Li, S.; Li, Y.; Li, Y.; Tan, H. Soot formation during biomass pyrolysis: Effects of temperature, waterleaching, and gas-phase residence time. J. Anal. Appl. Pyrolysis 2018, 134, 484-494.

(14) Wiinikka, H.; Toth, P.; Jansson, K.; Molinder, R.; Broström, M.; Sandström, L.; Lighty, J. S.; Weiland, F. Particle formation during pressurized entrained flow gasification of wood powder: Effects of process conditions on chemical composition, nanostructure, and reactivity. Combust. Flame 2018, 189, 240-256.

(15) Billaud, J.; Valin, S.; Peyrot, M.; Salvador, S. Influence of H 2 $\mathrm{O}, \mathrm{CO} 2$ and $\mathrm{O} 2$ addition on biomass gasification in entrained flow reactor conditions: Experiments and modelling. Fuel 2016, 166, 166178.

(16) Weiland, F.; Sweeney, D. J.; Wiinikka, H. Extractive Sampling of Gas and Particulates from the Reactor Core of an Entrained Flow Biomass Gasifier. Energy Fuels 2016, 30, 6405-6412. 
(17) Septien, S.; Valin, S.; Peyrot, M.; Dupont, C.; Salvador, S. Characterization of char and soot from millimetric wood particles pyrolysis in a drop tube reactor between $800^{\circ} \mathrm{C}$ and $1400^{\circ} \mathrm{C}$. Fuel 2014, 121, 216-224.

(18) Overend, R. P.; Misra, M. K.; Ragland, K. W.; Baker, A. J. Wood ash composition as a function of furnace temperature. Biomass Bioenergy 1993, 4, 103-116.

(19) Trubetskaya, A.; Jensen, P. A.; Jensen, A. D.; Garcia Llamas, A. D.; Umeki, K.; Gardini, D.; Kling, J.; Bates, R. B.; Glarborg, P. Effects of several types of biomass fuels on the yield, nanostructure and reactivity of soot from fast pyrolysis at high temperatures. Applied Energy 2016, 171, 468-482.

(20) Qin, K.; Lin, W.; Fæster, S.; Jensen, P. A.; Wu, H.; Jensen, A. D. Characterization of Residual Particulates from Biomass Entrained Flow Gasification. Energy Fuels 2013, 27, 262-270.

(21) Ma, J. Soot Formation during Coal Pyrolysis. Ph.D. thesis, Brigham Young University, 1996.

(22) Yang, Y.; Lin, X.; Li, S.; Luo, M.; Yin, J.; Wang, Y. Formation factors and emission characteristics of ultrafine particulate matters during Na-rich char gasification. Fuel 2019, 253, 781-791.

(23) Wen, C.; Gao, X.; Yu, Y.; Wu, J.; Xu, M.; Wu, H. Emission of inorganic PM10 from included mineral matter during the combustion of pulverized coals of various ranks. Fuel 2015, 140, 526-530.

(24) Chen, X.; Liaw, S. B.; Wu, H. Effect of volatile-char interactions on PM10 emission during the combustion of biosolid chars under air and oxyfuel conditions. Combust. Flame 2018, 197, 290-303.

(25) Tian, C.; Lu, Q.; Liu, Y.; Zeng, H.; Zhao, Y.; Zhang, J.; Gupta, $\mathrm{R}$. Understanding of physicochemical properties and formation mechanisms of fine particular matter generated from Canadian coal combustion. Fuel 2016, 165, 224-234.

(26) Gao, X.; Rahim, M. U.; Chen, X.; Wu, H. Significant contribution of organically-bound $\mathrm{Mg}, \mathrm{Ca}$, and $\mathrm{Fe}$ to inorganic PM10 emission during the combustion of pulverized Victorian brown coal. Fuel 2014, 117, 825-832.

(27) Gao, Q.; Li, S.; Yuan, Y.; Zhang, Y.; Yao, Q. Ultrafine particulate matter formation in the early stage of pulverized coal combustion of high-sodium lignite. Fuel 2015, 158, 224-231.

(28) Gai, Z.; Zhang, R.; Bi, J. Characteristics of Soot from Rapid Pyrolysis of Coal and Petroleum Coke. Energy Fuels 2017, 31, 37593767.

(29) Deng, C.; Liaw, S. B.; Wu, H. Characterization of SizeSegregated Soot from Pine Wood Pyrolysis in a Drop Tube Furnace at $1300{ }^{\circ} \mathrm{C}$. Energy Fuels 2019, 33, 2293-2300.

(30) Li, Y.; Wang, X.; Tan, H.; Bai, S.; Mikulčić, H.; Yang, F. Evolution of PM2.5 from biomass high-temperature pyrolysis in an entrained flow reactor. J. Energy Inst. 2019, 92, 1548-1556.

(31) Trubetskaya, A.; Jensen, P. A.; Jensen, A. D.; Steibel, M.; Spliethoff, H.; Glarborg, P.; Larsen, F. H. Comparison of high temperature chars of wheat straw and rice husk with respect to chemistry, morphology and reactivity. Biomass Bioenergy 2016, 86, 76-87.

(32) Molinder, R.; Öhrman, O. G. W. Characterization and Cleanup of Wastewater from Pressurized Entrained Flow Biomass Gasification. ACS Sustainable Chem. Eng. 2014, 2, 2063-2069.

(33) Arvelakis, S.; Jensen, P. A.; Dam-Johansen, K. Simultaneous thermal analysis (STA) on ash from high-alkali biomass. Energy Fuels 2004, 18, 1066-1076.

(34) Vassilev, S. V.; Baxter, D.; Vassileva, C. G. An overview of the behaviour of biomass during combustion: Part II. Ash fusion and ash formation mechanisms of biomass types. Fuel 2014, 117, 152-183.

(35) Ma, T.; Fan, C.; Hao, L.; Li, S.; Jensen, P. A.; Song, W.; Lin, W.; Dam-Johansen, K. Biomass ash induced agglomeration in fluidized bed. Part 2: Effect of potassium salts in different gas composition. Fuel Process. Technol. 2018, 180, 130-139.

(36) Yang, H.; Wang, D.; Li, B.; Zeng, Z.; Qu, L.; Zhang, W.; Chen, $\mathrm{H}$. Effects of potassium salts loading on calcium oxide on the hydrogen production from pyrolysis-gasification of biomass. Bioresour. Technol. 2018, 249, 744-750.
(37) Hu, B.; Huang, Q.; Bourtsalas, A. C. T.; Ali, M.; Chi, Y.; Yan, J. Effect of Chlorine on the Structure and Reactivity of Char Derived from Solid Waste. Energy Fuels 2017, 31, 7606-7616.

(38) Feng, L.; Wu, Y.; Xu, K.; Zhang, H.; Zhang, Y.; Zhang, M. Coal-Derived Soot Behaviors in O2/N2 and O2/CO2 Atmospheres, Studied through a 1-D Transient Coal Combustion Model. Energy Fuels 2019, 33, 3620-3629.

(39) Xu, M.; Yu, D.; Yao, H.; Liu, X.; Qiao, Y. Coal combustiongenerated aerosols: Formation and properties. Proc. Combust. Inst. 2011, 33, 1681-1697.

(40) Xu, M.-X.; Wu, Y.-C.; Nan, D.-H.; Lu, Q.; Yang, Y.-P. Effects of gaseous agents on the evolution of char physical and chemical structures during biomass gasification. Bioresour. Technol. 2019, 292, 121994.

(41) Zhang, R.; Lei, K.; Ye, B. Q.; Cao, J.; Liu, D. Effects of alkali and alkaline earth metal species on the combustion characteristics of single particles from pine sawdust and bituminous coal. Bioresour. Technol. 2018, 268, 278-285.

(42) Wei, J.; Gong, Y.; Ding, L.; Yu, J.; Yu, G. Influence of Biomass Ash Additive on Reactivity Characteristics and Structure Evolution of Coal Char-CO2 Gasification. Energy Fuels 2018, 32, 10428-10436.

(43) Wei, J.; Gong, Y.; Guo, Q.; Chen, X.; Ding, L.; Yu, G. A mechanism investigation of synergy behaviour variations during blended char co-gasification of biomass and different rank coals. Renew Energ 2019, 131, 597-605. 